\title{
Environmental Flow Assessment Using Water-Sediment Approach at the Sekampung River, Indonesia
}

\author{
Endro Prasetyo Wahono ${ }^{1,2 *}$, Djoko Legono ${ }^{2}$, Istiarto², Bambang Yulistiyanto² \\ ${ }^{1}$ Department of Civil Engineering, The University of Lampung, Bandar Lampung, Indonesia \\ ${ }^{2}$ Department of Civil and Environmental Engineering, Universitas Gadjah Mada, Yogyakarta, Indonesia \\ Email: ${ }^{*}$ epwahono@eng.unila.ac.id
}

Received 11 August 2014; revised 11 September 2014; accepted 9 October 2014

Copyright (C) 2014 by authors and Scientific Research Publishing Inc.

This work is licensed under the Creative Commons Attribution International License (CC BY).

http://creativecommons.org/licenses/by/4.0/

(c) () D Den Access

\begin{abstract}
Environmental issue has been considered more significant in many aspects of engineering decision-making process particularly in river management. There is an increasing effort to conserve functioning of rivers for human use as well as nature, therefore environmental flow assessment has been widely developed. This paper discusses on environmental flow assessment of the Sekampung River, particularly on its middle reach. A new analytical approach based on water-sediment equations was introduced in order to determine a minimum environmental flow at the certain cross section of a river. The result of the new method was then compared with a minimum environmental flow provided by using two hydrological based methods, namely, Tennant and Flow Duration Curve Analysis (FDCA) method. The result shows that the concerned discharge provided by the water-sediment method $\left(3.5 \mathrm{~m}^{3} / \mathrm{s}\right)$ is the smallest compare with a minimum environmental flow that is provided by both Tennant $\left(5.7 \mathrm{~m}^{3} / \mathrm{s}\right)$ and FDCA method $\left(4.5 \mathrm{~m}^{3} / \mathrm{s}\right)$. It is promising that the water-sediment method can be used as a simple approach on preliminary state of environmental flow assessment. The method involves not only water discharge but also its related sediment flow of the river in order to mitigate further ecological and morphological risks.
\end{abstract}

\section{Keywords}

Water-Sediment, Environmental Flow, River Morphology

\section{Introduction}

In the recent years, environmental issue has been considered more significant in many aspects of engineering

${ }^{*}$ Corresponding author.

How to cite this paper: Wahono, E.P., Legono, D., Istiarto and Yulistiyanto, B. (2014) Environmental Flow Assessment Using Water-Sediment Approach at the Sekampung River, Indonesia. Open Journal of Modern Hydrology, 4, $164-172$. 
decision-making process. It is even more considerable regarding environmental natural disaster management. Environmental flow requirements, among others, are being assessed for an increasing number of rivers worldwide. Numerous methods are used ranging from simple to complex. Not only the ecological water needs are assessed, but also the local demands of human communities along the river are taken into account.

Awareness of that a certain amount of water needs to remain flowing in the river forms a new challenge for river management as an extra demand is now competing for the scarce water resource. Internationally this awareness is reflected in the Global Dialogue on Water, Food and Environment, which has started in the wake of the Second World Water Forum of March 2002.

It has been stated that the amount of the original river flow regime required to maintain specified valued features of the river ecosystem is generally referred to the Environmental Flow Requirement (EFR) [1]. The term of in-stream flow requirements, Maintenance Flow Requirements and Ecological Flow Requirements are used as well, to emphasise the fact that water has to maintain dedicated for the river ecosystem.

Although the demands for irrigation, navigation, industries and other water users can be assessed relatively straightforward, there is still much uncertainty about how the EFR should be defined. The practice of EFR began as a commitment to ensuring a "minimum flow" in the river, often arbitrarily fixed at $10 \%$ of the main annual runoff. Further scientific evidence and experience are available that question the "minimum flow" approach and there is now a general opinion that for safeguarding essential downstream environmental conditions the dynamics of the river flow should be taken into account. However, the approach regarding a minimum environmental flow has been widely chosen due to its simplicity. Several Environmental Flow Assessment (EFA) methods have been developed over the years to acknowledge the complexity of the flow-environment relationship.

Reviews (e.g. [2]-[4]) generally identify four types of EFA methods, namely, hydrological, hydraulic rating, habitat simulation, and holistic methods, as well as combinatorial and other approaches [5] [6]. Each type of method has its own strengths and weaknesses. This raises a question about which method is appropriate in a certain context. Some methods are quantitative by nature (hydrological and hydraulic methods). They determine environmental flows based on flow records. These methods, however, leave the functions of river-ecosystem as aspects that has to be considered. In other words the method is not transparent. Other methods (holistic methods) try to include all functions of the river-ecosystem, but are usually based on expert judgement and are therefore difficult to reproduce. Hence, there is not one method that comprises all river-ecosystem functions in a quantitative way with explicit and scientifically justified links between the functions and required flows.

The scarceness of riverine environmental data makes it difficult to use such methods as habitat simulation methods [7] [8], holistic methods [9] [10] and combined methods [11]. Hydrological methods, such as the Tennant method [12] and Texas method [13], have the advantages of simple computation and easy handling, therefore it is appropriate for preliminary stage of the environmental flow assessment particularly on the basin level. However, they not only often oversimplify the actual situation of a river, but also fail to consider biological parameters and their interactions [14]. In practice, they are more appropriate for natural rivers and are generally used as a rough verification of other approaches [15]. Traditional hydraulic rating methods, such as Wetted Perimeter method [12] [15] and R2CROSS method, are readily applied due to a small data requirement, but they are unable to estimate the seasonal variations of environmental flows [15]. Therefore, a study of the most suitable method for a concerned river is necessary. The most suitable method will particularly depends on the availability of data required. A new modification method based on site condition is also required.

In the Sekampung River basin, there is a lack of river ecological data and limited hydrological data as most Indonesian rivers do. This paper discusses on preliminary study of the EFA for the Sekampung River. The river is one of the most important rivers in the Lampung Province. Having catchment area of 796 kilometre square and total length of 256 kilometre, the river supplies for more than 40.000 acre irrigation area within the province. Typical cross section of the river has $30 \mathrm{~m}$ of main channel width and about $250 \mathrm{~m}$ of floodplain length [16].

\section{Research Approach}

\subsection{General}

Thus far, only a few assessments of either the numbers of individual methodologies has been utilized for Environmental Flow Assessments in Indonesia. The emphasis in this paper is on the preliminary study of environmental flow required for river ecosystems, including their floodplains, of the Way Sekampung River. The inten- 
tion of this paper is to introduce relation between magnitude and frequency of the discharge, morphological aspect and their corresponding environmental flow, in addition, comparison was also provided to have an overview what will be the reasonable discharge range of environmental flow for the Sekampung River, particularly on its middle reach.

Moreover, time series discharge data from 2001 to the year of 2010 has been analysed using several methods, namely, Tennant method [12], Flow Duration Curve Analysis (FDCA) and the new approach of the magnitudefrequency approach.

Regarding the methods, Richter [17] highlighted the Tennant (Montana) method as the second most widely used environmental flow method in North America. Since then, it has become the most commonly applied hydrological methodology worldwide. Although superficially a standard-setting approach, the method, developed in the United States by Tennant and the US Fish and Wildlife Service, differs from many other hydrological methodologies in that considerable collection of field habitat, hydraulic and biological data was involved in its development. It comprises a table linking different percentages of average or mean annual flow (AAF/MAF) to different categories of river condition, on a seasonal basis, as the recommended minimum flows. The categories of flow-related condition range from "poor or minimum" (10\% AAF) to "optimum range" (60\% - 100\% AAF) [4]. At least twenty five countries have either applied the method as originally expounded by Tennant in 1976, in a modified form on the basis of various hydrological, geo-morphological, ecological or catchment-based criteria [11] or have simply utilized various (often arbitrarily designated) percentages or ranges of AAF. Several forms of the basic approach exist in North America particularly, and Leonard [14] provides an example of a modification of the method for use in eastern and Eastern and Southeastern United States, with the addition of specialist know- ledge of fish ecology, flow duration estimates, and a mean monthly flow index.

In this research the FDCA was also used to study probability distribution of recorded data. Using the FDCA, data was ranked and calculated its corresponding probability by using the following equation:

$$
P=(m / n+1) 100 \%
$$

In this paper, a new approach using analytical approach for a minimum environmental flow assessment was also formulated. The model is basically based on equations of water flow as well as sediment transport. The method is developed to provide a minimum discharge which assumed to be the main force of sediment movement at the specified river cross section. A corresponding graph was then produced based on the derived equation which related to the magnitude-frequency approach of water-sediment relationship.

\subsection{Data Acquisition and Location}

Data used for the environmental flow analysis of this research were collected from the discharge measurement stations (AWLR) at the downstream of the Argoguruh Weir as the measurement is conducted by the technical implementation unit (UPTD Balai Pengelola Sumber Daya Air) of the Sekampung River at Metro. Discharge data of a ten years period from 2001 to the year of 2010 consisting of 3.070 data were chosen to provide reasonable pattern of the river flow.

The Argoguruh Weir was the main concern of this paper since the weir has a prominent role to support the main irrigation area of the Sekampung River. The regulated structure is located at the meddle reach of the Sekampung River which has a total long of 256 kilometres originating from its spring in the Bukit Barisan mountain to the Eastern coast of Sumatra (Java Sea). Total annual rainfall of the river catchment ranged between $1600 \mathrm{~mm}$ to $2500 \mathrm{~mm}$ [16]. The maximum annual rainfall mostly occurred at the upstream reach of the river.

Research site of this work is located on the down-stream site of the Argoguruh weir in the village of Metro Kibang as presented in Figure 1.

\section{Result and Discussion}

Environmental flow analysis is essential to provide knowledge of linkage between water resources use and ecological boundaries. It is also important to answer of the general question whether operation the Batutegi Dam has been affecting ecological pattern of the Way Sekampung River. Learned from the river hydrograph as presented in Figure 2, there is no significant changes on high flows (higher than $100 \mathrm{~m}^{3} / \mathrm{s}$ ) both on its pattern of occurrence and values. However environmental flow will also affected by how the low flow of the river behaves. 
Based on recommendation stated by Tennant, an environmental flow (EF) was provided. The environmental flow was mainly driven by time series data of the daily discharge. Annual average discharge was calculated from 3070 data and the discharge of $57.3 \mathrm{~m}^{3} / \mathrm{s}$ is defined as Annual Average Flow (AAF). The environmental flow provided is vary from $10 \% \mathrm{AAF}$ to $60 \%-100 \% \mathrm{AAF}$ as an optimum values.

Regarding the AAF of the Sekampung River, the optimum environmental flow was then also provided as an interval of $34.3 \mathrm{~m}^{3} / \mathrm{s}$ to AAF $\left(57.3 \mathrm{~m}^{3} / \mathrm{s}\right)$. Meanwhile the minimum discharge that has to be maintained for environmental flow in middle reach of the Sekampung River $5.73 \mathrm{~m}^{3} / \mathrm{s}(10 \%$ AAF). The other environmental value as categorised by Tennant is presented in Table 1 .

Meanwhile using FDCA method, the discharge of $32.08 \mathrm{~m}^{3} / \mathrm{s}$ is defined as $50 \%$ of probability that can be assigned as mean value. Regarding Figure 3 that provides probability curve of the data concerned, it is also found that to maintain the probability of $95 \%$ of the river flow then the value of $4.5 \mathrm{~m}^{3} / \mathrm{s}$ has to be concerned. Compare to the Tennant method, the $50 \%$ of probability $\left(32.08 \mathrm{~m}^{3} / \mathrm{s}\right)$ is categorised as Outstanding (between $40 \%-60 \%$ AAF). However the discharge with $95 \%$ of probability is even lower than the $10 \%$ AAF that means lower than the minimum threshold set by Tennant.

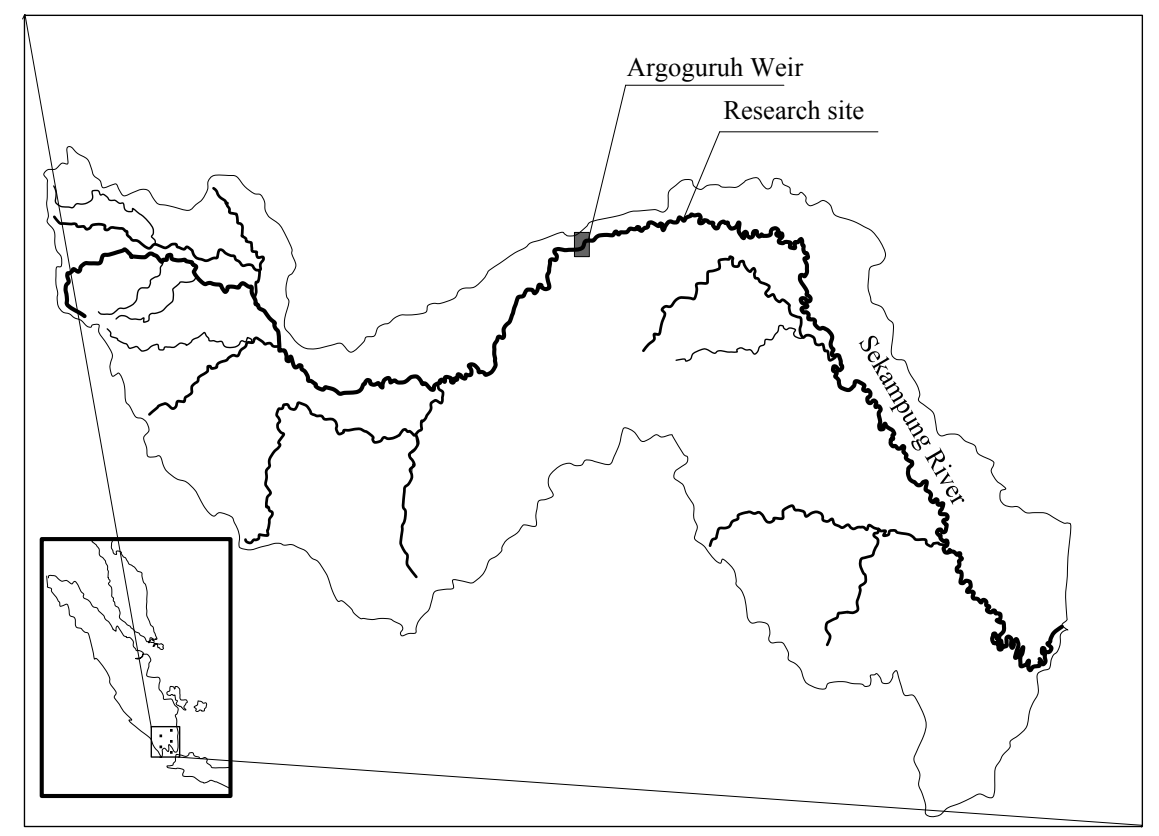

Figure 1. The Argoguruh weir at middle reach of the way Sekampung River, Indonesia.

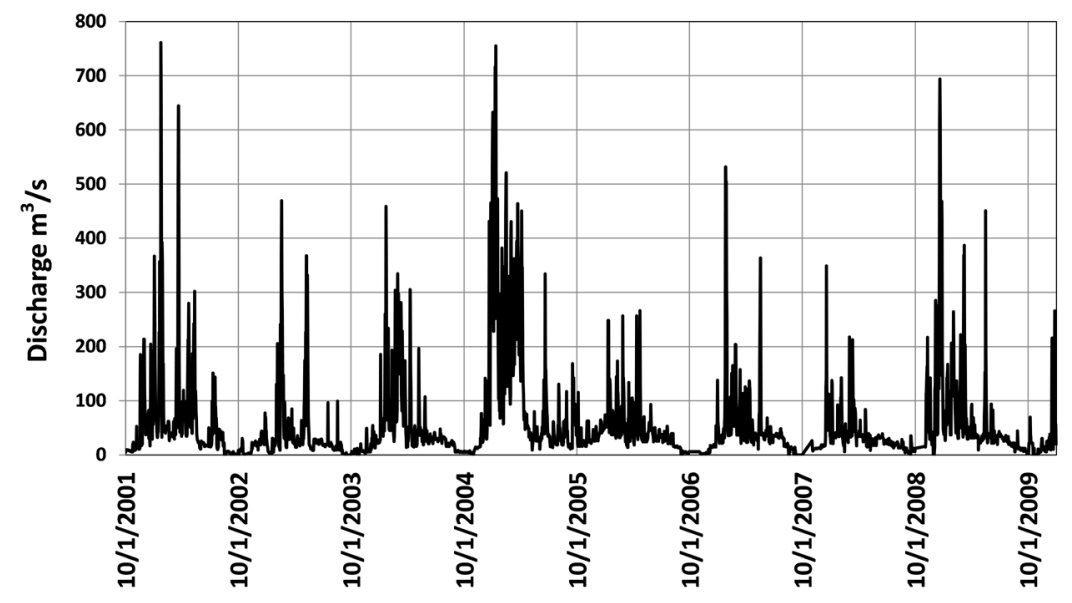

Figure 2. Discharge of the way Sekampung Rivet at Argoguruh weir. 


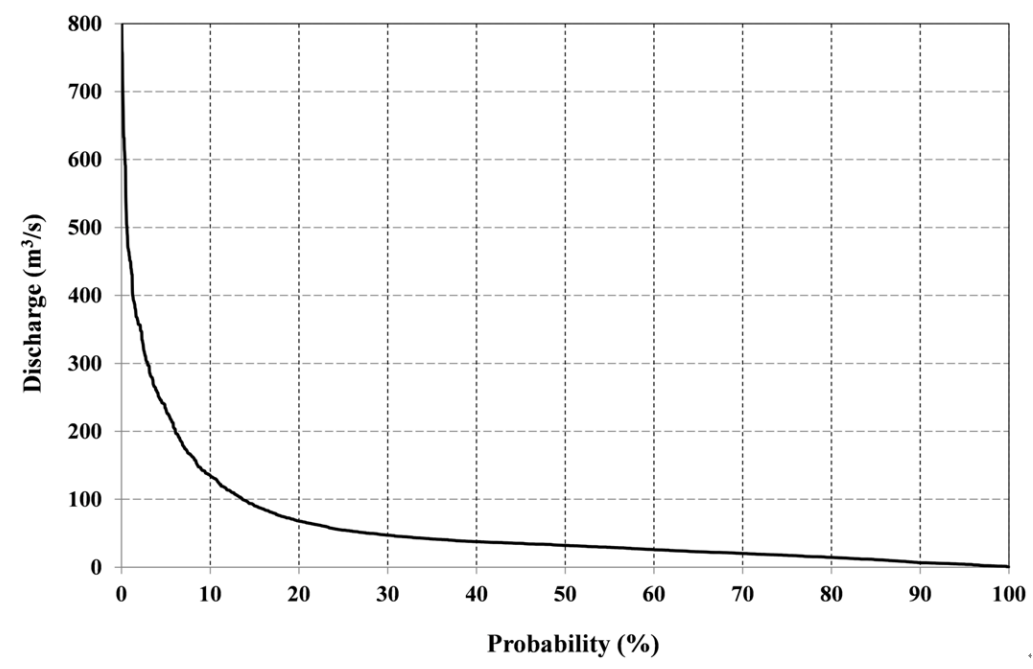

Figure 3. Flow duration curve of the way Sekampung River at Argoguruh weir.

Table 1. Environmental flow for middle reach of the Sekampung River.

\begin{tabular}{|c|c|c|c|c|}
\hline \multirow{2}{*}{ Description of discharges } & \multicolumn{2}{|c|}{ Recommended base flow regime (\%) } & \multicolumn{2}{|c|}{ Discharge $\left(\mathrm{m}^{3} / \mathrm{s}\right)$} \\
\hline & Oct.-Mar. & Apr.-Sept. & Oct.-Mar. & Apr.-Sept. \\
\hline Average annual flow & \multicolumn{2}{|c|}{$100 \%$ average flow } & \multicolumn{2}{|c|}{57.306} \\
\hline Flushing or maximum & \multicolumn{2}{|c|}{$200 \%$ average flow } & \multicolumn{2}{|c|}{114.611} \\
\hline Optimum range & \multicolumn{2}{|c|}{$60 \%-100 \%$ average flow } & \multicolumn{2}{|c|}{$34.383-57.306$} \\
\hline Outstanding & $40 \%$ & $60 \%$ & 22.922 & 34.383 \\
\hline Excellent & $30 \%$ & $50 \%$ & 17.192 & 28.653 \\
\hline Good & $20 \%$ & $40 \%$ & 11.461 & 22.922 \\
\hline Fair or degrading & $10 \%$ & $30 \%$ & 5.731 & 17.192 \\
\hline Poor or minimum & $10 \%$ & $10 \%$ & 5.731 & 5.731 \\
\hline Severe degradation & \multicolumn{2}{|c|}{$10 \%$ average flow to zero flow } & \multicolumn{2}{|c|}{$5.731-0$} \\
\hline
\end{tabular}

A new analytical approach of water-sediment that based on magnitude-frequency method is intended to provide more simple method and reasonable value of environmental flow since the ecological variables of the river are not only depended on the flow pattern but also on the bed-load sediment rate. In this water-sediment approach, resultant of the magnitude of river discharge and their corresponding frequency, which is related to frequent discharge, will represent the most prominent flow available in the river. Although value and duration of the high flow is also important, the most dominant discharge provides positive correlation to the shape of river's cross section. Meanwhile the minimum value of water-sediment curve is related to the dominant ecological pattern of the river. Since the minimum environmental flow is the main concern then the minimum value of water-sediment of the river is represent the point of concern.

Discharge has been widely used as a tool to study morphological aspect of a river [18]. For example, among number of researchers, Wilkerson and Parker [19] stated that bankfull discharge tends to have a significant relation with morphological changes of a river. Number of researchers [19] [20] defines a bankfull discharge as a function of river's geometry namely: wetted perimeter, top width and particle diameter of the river-bed $\left(D_{50}\right)$. Wahono [21] state that discharges of higher than the dominant discharge will provide significant effects on the morphology changes of a river-bed.

Jansen within [22] described there are four basic assumptions as a tools to arrive in one dimensional analytical approach of river morphology those are:

1. Momentum equation of water movement:

$$
\frac{\partial u}{\partial t}+u \frac{\partial u}{\partial x}+g \frac{\partial h}{\partial x}+g \frac{\partial z}{\partial x}=-g \frac{u|u|}{C^{2} h}
$$


which can be expressed as Chezy equation of water flow within steady and uniform flow

$$
Q=B C h^{3 / 2} i^{1 / 2}
$$

2. Continuity equation of water:

$$
\frac{\partial a}{\partial t}+u \frac{\partial h}{\partial x}+h \frac{\partial u}{\partial x}=0
$$

3. Sediment continuity:

$$
\frac{\partial z}{\partial t}+\frac{\partial s}{\partial x}=0
$$

4. Sediment transport predictor:

$$
s=m u^{n}
$$

which $m$ and $n$ are coefficients. Klaassen at [23] provides equation of sediment predictor as the following:

$$
s=D^{-P} m u^{n}
$$

By combining those equations, Equations (6) and (7), and introducing $B$ as river width, then the equation will be as the following:

$$
(S=s \cdot B): S=B D^{-P} m u^{n}=B D^{-P} m C^{n}(h i)^{n / 2}
$$

When Chezy equation is used to represent velocity: $u=C(h i)^{\frac{1}{2}}$ where $C$ is Chezy coefficient and $h$ is the water flow depth.

Moreover, a relation among variables within alluvial system can be written as:

$$
S D:: Q i
$$

By integrating Equations (8) and (9) it can be provided an equation that not only based on the qualitative approach as Equation (9). With $S=$ sediment discharge $\left(\mathrm{m}^{3} / \mathrm{s}\right), Q=$ water discharge $\left(\mathrm{m}^{3} / \mathrm{s}\right), D=$ diameter of river-bed's grain size $(\mathrm{m})$ and $i=$ energy gradient $(\mathrm{m} / \mathrm{m})$. It will come to the following equation:

$$
S D^{p} B^{\frac{n-3}{3}}:: m C^{\frac{2 n}{3}} Q^{\frac{n}{3}} i^{\frac{n}{3}}
$$

That can be expressed as:

$$
S D^{p} B^{\frac{n-3}{3}}:: Q^{\frac{n}{3}} i^{\frac{n}{3}}
$$

By assuming :: is "proportional to" and replacing $n$ and $p$ using predictor of Engelund-Hansen, Klaassen [23] reported that $n$ and $p$ are replaced by 5 and 1 respectively, then Equation (11) can be expressed as the following:

$$
S D^{1} B^{\frac{2}{3}}:: Q^{\frac{5}{3}} i^{\frac{5}{3}}
$$

in case of $D, B$ and $i$ are assumed to be constant then sediment rate $(S)$ will be proportional to discharge and its frequency of occurrence $(F)$

$$
S:: F_{i} Q^{\frac{5}{3}}
$$

Using Equation (13), it can be provided the relationship between probability of the discharge-sediment and average discharge $Q$ as presented in Figure 4. This figure is also known as magnitude-frequency approach of sediment-water relationship. The graph shows that discharge of $38 \mathrm{~m}^{3} / \mathrm{s}$ is the represent dominant discharge of the concerned river reach and it is also can be seen that discharge of about $3.5 \mathrm{~m}^{3} / \mathrm{s}$ as the lowest discharge on the graph represents the minimum environmental flow of the concerned site.

Using the water-sediment method that represents magnitude-frequency of water as well as its corresponding sediment flow, frequency diagram of the entire data was provided as presented in Figure 4. It has to be noted 


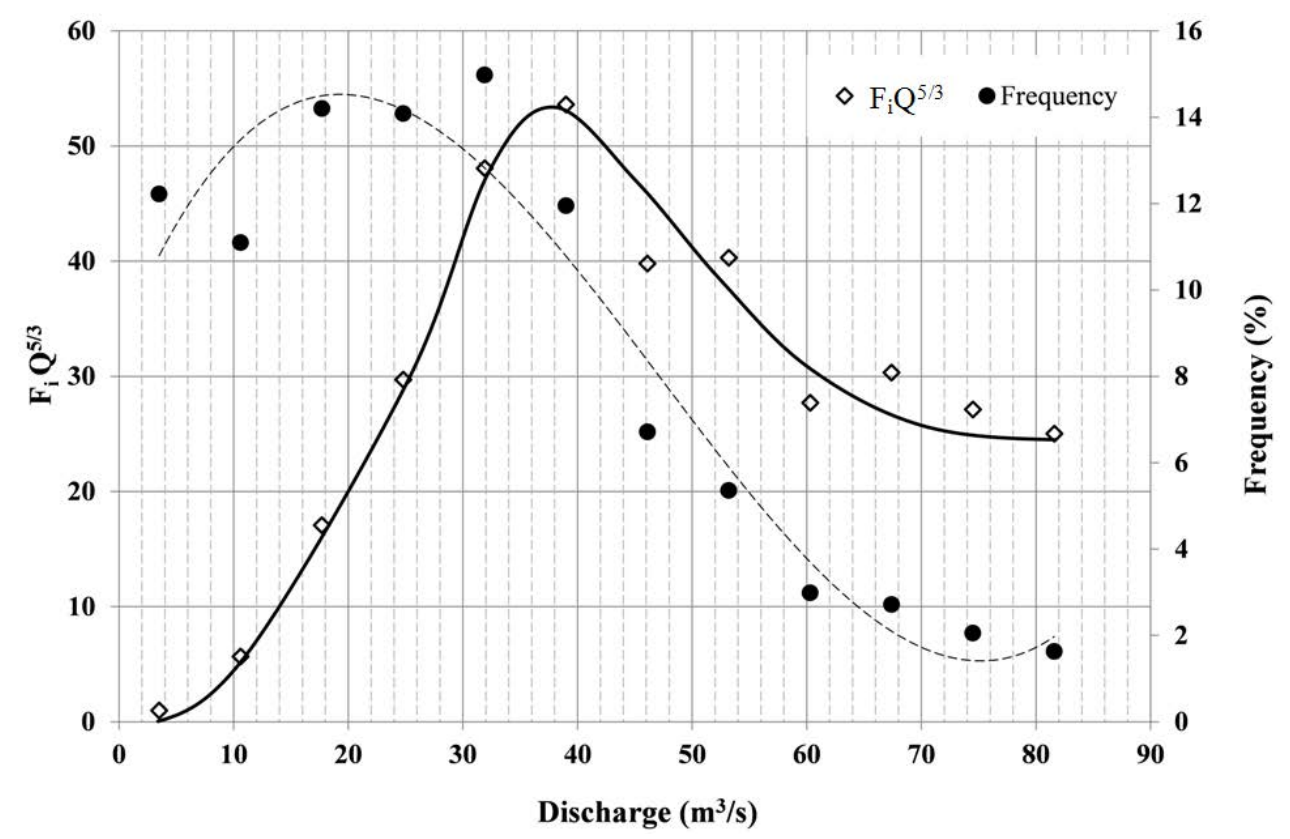

Figure 4. Magnitude-frequency of the Sekampung River.

that applicability of the method is limited to the condition of ideal sediment transport.

Discharge data between $0 \mathrm{~m}^{3} / \mathrm{s}$ and $100 \mathrm{~m}^{3} / \mathrm{s}$ classified into thirteen consecutive equal intervals and also calculated its corresponding frequencies. It is found that discharge of $20 \mathrm{~m}^{3} / \mathrm{s}$ has the highest frequency (peak of the curve) and identified as the frequent discharge (Qf) which also corresponding to a $38 \mathrm{~m}^{3} / \mathrm{s}$ discharge called the dominant discharge $(\mathrm{Qd})$. Meanwhile the main concern of a minimum environmental flow is adjusted from the minimum value of the water-sediment graph. From Figure 4, it can be learned that value of the minimum water-sediment is represented by the smallest value of the curve representing Equation (13). Based on Figure 4, the value is provided as $3.5 \mathrm{~m}^{3} / \mathrm{s}$. The minimum environmental flow of $3.5 \mathrm{~m}^{3} / \mathrm{s}$ is about $10 \%$ of the dominant discharge which is $38 \mathrm{~m}^{3} / \mathrm{s}$. The percentage will however tend to be depended on the cross section characteristic of the river.

Compare to the Tennant method, the result of the water-sediment method $\left(3.5 \mathrm{~m}^{3} / \mathrm{s}\right)$ is categorised as severe class or equivalent to a range of $10 \%$ to $0 \%$ AAF. Meanwhile, regarding the FDCA method, the value of defined environmental flow has a probability of about $95 \%$ or equal to $95 \%$ dependable discharge.

\section{Conclusions}

A preliminary study of environmental flow of the Sekampung River was conducted using number of methods including a new method called water-sediment method and it was concluded that the optimum environmental flow regarding Tennant method was an interval from $34.3 \mathrm{~m}^{3} / \mathrm{s}$ to AAF $\left(57.3 \mathrm{~m}^{3} / \mathrm{s}\right)$. Meanwhile, according to the Tennant method, the poor or minimum category of discharge that has to be maintained in the middle reach of the Sekampung River is $5.73 \mathrm{~m}^{3} / \mathrm{s}(10 \% \mathrm{AAF})$.

Using the water-sediment method, it is found that discharge of $20 \mathrm{~m}^{3} / \mathrm{s}$ is identified as the frequent discharge. It also provides discharge of $38 \mathrm{~m}^{3} / \mathrm{s}$ as the dominant discharge of the river site. Meanwhile the discharge of 3.5 $\mathrm{m}^{3} / \mathrm{s}$ is classified as a minimum environmental flow.

Compare with the Tennant method, the discharge of $3.5 \mathrm{~m}^{3} / \mathrm{s}$ is categorised as the lowest criteria (less than $10 \% \mathrm{AFF}$ ). Meanwhile $20 \mathrm{~m}^{3} / \mathrm{s}$ is categorised as outstanding class or equivalent to a range of $40 \%$ to $60 \% \mathrm{AAF}$.

Regarding the FDCA method, the value of $3.5 \mathrm{~m}^{3} / \mathrm{s}$ has a probability of $95 \%$. Therefore, after comparing all concerned methods, the result from the new method called water-sediment is more likely close to the minimum discharge set by Tennant, and $95 \%$ of dependable discharge regarding the FDCA method.

Further developments of the method by taking into account both ecological aspect and parameters regarding sediment's initiation of motion have to be performed for a more comprehension approach. 


\section{Acknowledgements}

We would like to express my appreciation to Reni C. Pasaribu and Asep E. Saputra who have been working on this research. Authors would also like to thank Directorate Higher Education of Indonesia for providing financial support for this research. We appreciate for the anonymous peer reviewers of this journal for their comments and suggestions.

\section{References}

[1] Marchand, M. (2003) Environmental Flow Requirements for Rivers: An Integrated Approach for River and Coastal Zone Management. Project Report of Integrated Water Resources Management, Delft Cluster, Delft, 86.

[2] King, J. and Brown, C. (2006) Environmental Flows: Striking the Balance between Development and Resource Protection. Ecology and Society, 11, 26. http://www.ecologyandsociety.org/vol11/iss2/art26/

[3] Dunbar, M.J., Holmes, M.G.R. and Young, A.R. (2008) Guidance on Environmental Flow Releases from Impoundments to Implement the Water Framework Directive. SNIFER Report, Edinburgh, 51.

[4] Jowett, I.G. (1997) Instream Flow Methods: A Comparison of Approaches. Regulated Rivers: Research \& Management, 13, 115-127. http://dx.doi.org/10.1002/(SICI)1099-1646(199703)13:2<115::AID-RRR440>3.0.CO;2-6

[5] Tharme, R.E. (2003) A Global Perspective on Environmental Flow Assessment: Emerging Trends in The Development and Application of Environmental Flow Methodologies for Rivers. River Research and Application, 19, 397-441. http://dx.doi.org/10.1002/rra.736

[6] Chen, H. and Zhao, Y.W. (2011) Evaluating the Environmental Flows of China's Wolonghu Wetland and Land Use Changes Using a Hydrological Model, a Water Balance Model, and Remote Sensing. Ecological Modelling, 222, 253260. http://dx.doi.org/10.1016/j.ecolmodel.2009.12.020

[7] Milhous, R.T. (2009) An Adaptive Assessments of the Flushing Flow Needs of the Lower Poudre River, Colorado: First Evaluation. Proceeding of Hydrology Days 2009, Fort Collins, 25-27 March 2009, 46-56. https://wsnet.colostate.edu/cwis312/hydrologydays/Papers_2009/Milhous_paper.pdf

[8] Schneider, Matthias, Noack, M., Gebler, T. and Kopecki, I. (2010) Handbook for the Habitat Simulation Model. Casimir, Stuttgart, 52. http://www.casimir-software.de/data/CASiMiR Fish Handb EN 2010 10.pdf

[9] Arthington, A.H., Tharme, R.E., Brizga, S.O., Pusey, B.J. and Kennard, M.J. (2004) Environmental Flow Assessment with Emphasis on Holistic Methodologies. In: Welcomme, R.L. and Petr, T., Eds., Proceedings of the Second International Symposium of the Management of Large Rivers for Fisheries (Volume II), FAO \& MRC, Phnom Penh, 37-66. http://www.fao.org/docrep/007/ad526e/ad526e07.htm\#bm07

[10] King, J., Brown, C. and Sabet, H. (2003) A Scenario-Based Holistic Approach to Environmental Flow Assessments for Rivers. River Research and Application, 19, 619-639. http://dx.doi.org/10.1002/rra.709

[11] Acreman, M.C. and Dunbar, M.J. (2009) Defining Environmental River Flow Requirements—A Review. Journal of Hydrology and Earth System Sciences, 8, 861-876. http://dx.doi.org/10.5194/hess-8-861-2004

[12] Mann, J.L. (2006) Instream Flow Methodologies: An Evaluation of the Tennant Method for Higher Gradient Streams in the National Forest System Lands in the Western USA. M.Sc. Thesis, Colorado State University, Fort Collins, 143.

[13] Winemiller, K., Bonner, T., Brandes, B., Davis, S., King, R., Maidment, D. and Ward, G. (2008) Review of Desk-Top Methods for Establishing Environmental Flows in Texas Rivers and Streams. Texas Commission on Environmental Quality Report, Austin, 30.

[14] Leonard, P.M. (2011) Emerging Trends in Environmental Flow Science. Proceedings of the 2011 Georgia Water Resources Conference, Athens, 11-13 April 2011. http://gwri.gatech.edu/sites/default/files/files/docs/2011/4.2.2Leonard.pdf

[15] Liu, C.M., Zhao, C.S., Xia, J., Sun, C.L., Wang, R. and Liu, T. (2011) An Instream Ecological Flow Method for DataScarce Regulated Rivers. Journal of Hydrology, 398, 17-25. http://dx.doi.org/10.1016/j.jhydrol.2010.11.026

[16] Wahono, Prasetyo, E., Djausal, A., Mariyanto and Jokowinarno, D. (2003) River Maintenance Plan for Sekampung River. GGWRM-EU, Bandar Lampung, 140.

[17] Richter, B.D., Baumgartner, J., Wigington, R. and Braun, D. (1997) How Much Water Does a River Need? Freshwater Biology, 37, 231-249. http://dx.doi.org/10.1046/j.1365-2427.1997.00153.x

[18] Harman, C., Stewardson, M. and DeRose, R. (2008) Variability and Uncertainty in Reach Bankfull Hydraulic Geometry. Journal of Hydrology, 351, 13-25. http://dx.doi.org/10.1016/j.jhydrol.2007.11.015

[19] Wilkerson, G.V. and Parker, G. (2011) Physical Basis for Quasi-Universal Relationships Describing Bankfull Hydraulic Geometry of Sand-Bed Rivers. Journal of Hydraulic Engineering, 137, 739-753.

http://dx.doi.org/10.1061/(ASCE)HY.1943-7900.0000352 
[20] Seal, B.R., Paola, C., Parker, Z.G., Southard, J.B. and Wilcock, P.R. (1997) Experiments on Downstream Fining of Gravel. Journal of Hydraulic Engineering, 123, 874-884. http://dx.doi.org/10.1061/(ASCE)0733-9429(1997)123:10(874)

[21] Wahono, E.P. (2002) Behaviour of River-Bed Disturbances Due to Floodplain Naturalisation and Discharge Variation. M.Sc. Thesis, UNESCO-IHE Water Institute, Delft, 286.

[22] Ghani, A.A., Ali, R., Zakaria, N.A., Hasan, Z.A., Chang, C.K. and Ahamad, M.S.S. (2010) A Temporal Change Study of the Muda River System over 22 Years. International Journal of River Basin Management, 8, 25-37. http://dx.doi.org/10.1080/15715121003715040

[23] Klaassen, G.J. (1995) Lane's Balance Revisited. Proceedings of 6th International Symposium on River Sedimentation, New Delhi, 7-11 November 1995, 671-686. 
Scientific Research Publishing (SCIRP) is one of the largest Open Access journal publishers. It is currently publishing more than 200 open access, online, peer-reviewed journals covering a wide range of academic disciplines. SCIRP serves the worldwide academic communities and contributes to the progress and application of science with its publication.

Other selected journals from SCIRP are listed as below. Submit your manuscript to us via either submit@scirp.org or Online Submission Portal.
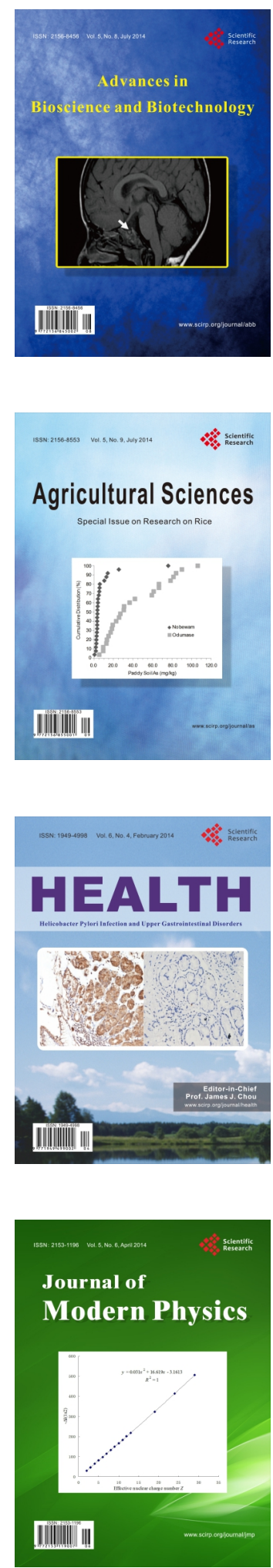
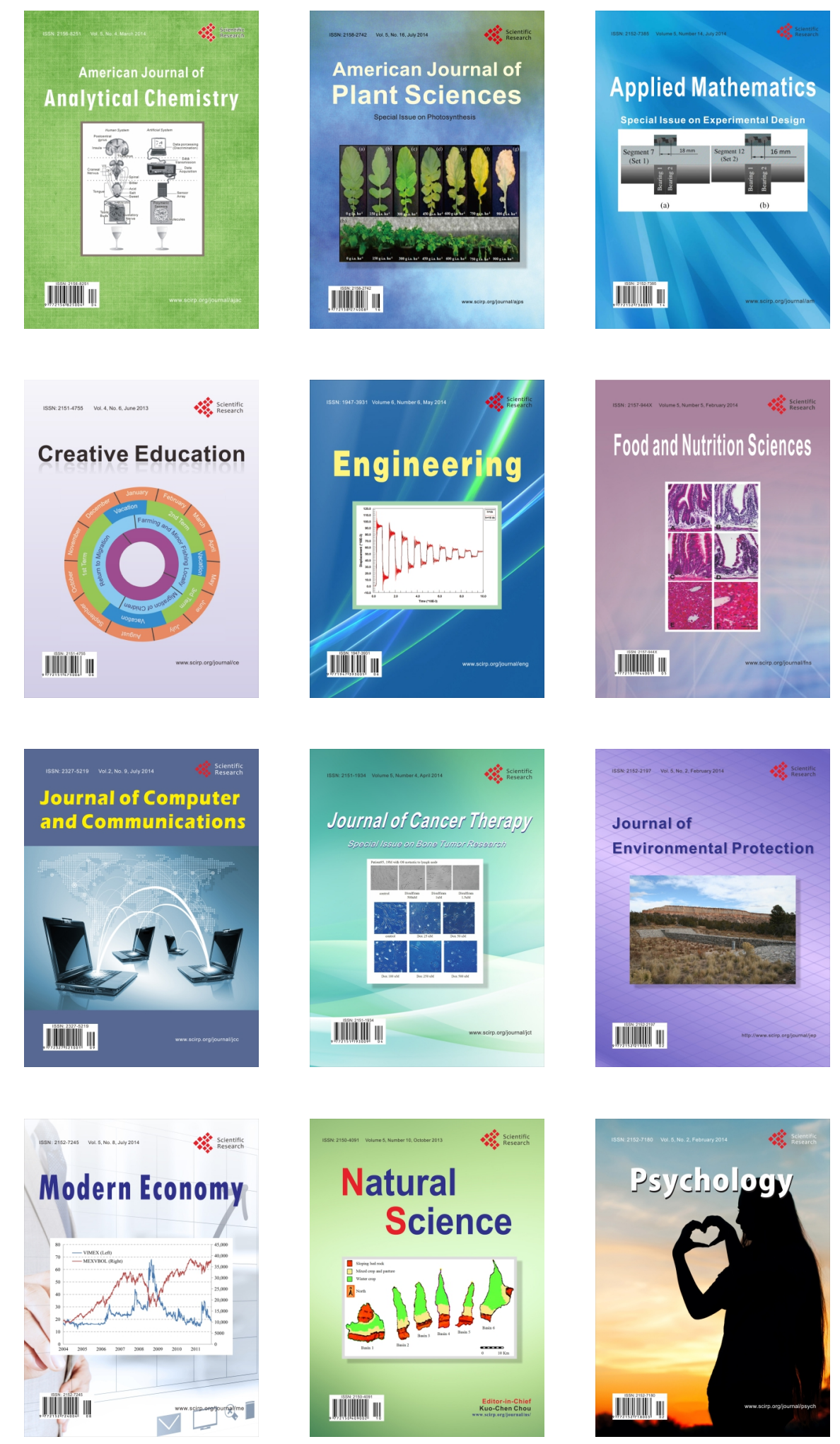